$D_{2.252}$

Potassium Vapor Topping Cycle

Technical Progress Report for Period October 1, 1977-December 31, 1977

Robert S. Holcomb

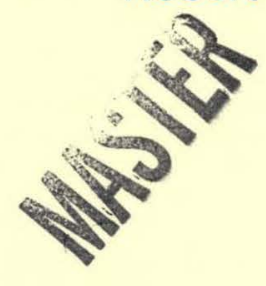

OAK RIDGE NATIONAL LABORATORY OPERATED BY UNION CARBIDE CORPORATION · FOR THE DEPARTMENT OF ENERGY 


\section{DISCLAIMER}

This report was prepared as an account of work sponsored by an agency of the United States Government. Neither the United States Government nor any agency Thereof, nor any of their employees, makes any warranty, express or implied, or assumes any legal liability or responsibility for the accuracy, completeness, or usefulness of any information, apparatus, product, or process disclosed, or represents that its use would not infringe privately owned rights. Reference herein to any specific commercial product, process, or service by trade name, trademark, manufacturer, or otherwise does not necessarily constitute or imply its endorsement, recommendation, or favoring by the United States Government or any agency thereof. The views and opinions of authors expressed herein do not necessarily state or reflect those of the United States Government or any agency thereof. 


\section{DISCLAIMER}

Portions of this document may be illegible in electronic image products. Images are produced from the best available original document. 
Printed in the United States of America. Available from Nationial Technical Infumaliun Service

U.S. Department of Commerce

5285 Port Royal Road, Springfield, Virginia 22161

Price: Printed Copy $\$ 4.50$; Microfiche $\$ 3.00$

This report was prepared as an account of work sponsored by an agency of the United States Government. Neither the United States Government nor any agency thereof, nor any of their employees, contractors, subcontractors, or their employees, makes any warranty, express or implied, nor assumes any legal liability or responsibility for any third party's use or the results of such use of any information, apparatus, product or process disclosed in this report, nor represents that its use by such third party would not infringe privalely uwned rights. 
ORNL/TM-6314

Dist. Category UC-90f

Contract No. W-7405-eng-26

Engineering Technology Division

POTASS IUM VAPOR TOPPING CYCLE

TECHNICAL PROGRESS REPORT FOR PERIOD

OCTOBER 1, 1977 - DECEMBER 31, 1977

Robert S. Holcomb



Date Published: July 1978

NOTICE This document contains information of a preliminary nature. It is subject to revision or correction and therefore does not represent a final report.

Prepared by the OAK RIDGE NATIONAL LABORATORY

Oak Ridge, Tennessee 37830 operated by

UNION CARBTDF CORPORATION

for the

DEPARTMENT OF ENERGY
NOT!CE

The repor prepared as an eccount of work Unied Frere States nor the United States Department of cons an af dicit any was, subcontractors, or their employees, makes liabiliy orty, express or implied, or assumes any legal or usefuresor or usefulness of any information, apparatus, product or process disclosed, or represents that its use would not iniringe privately owned rights. 


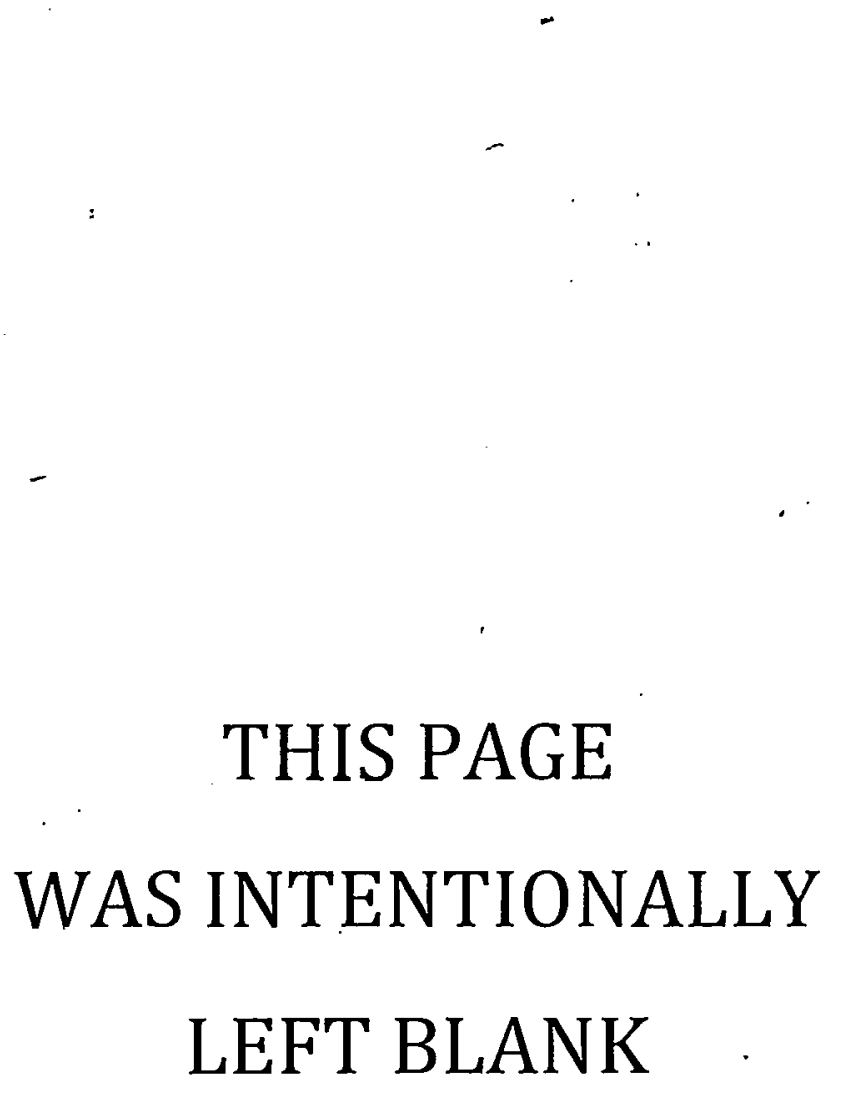


CONTENTS

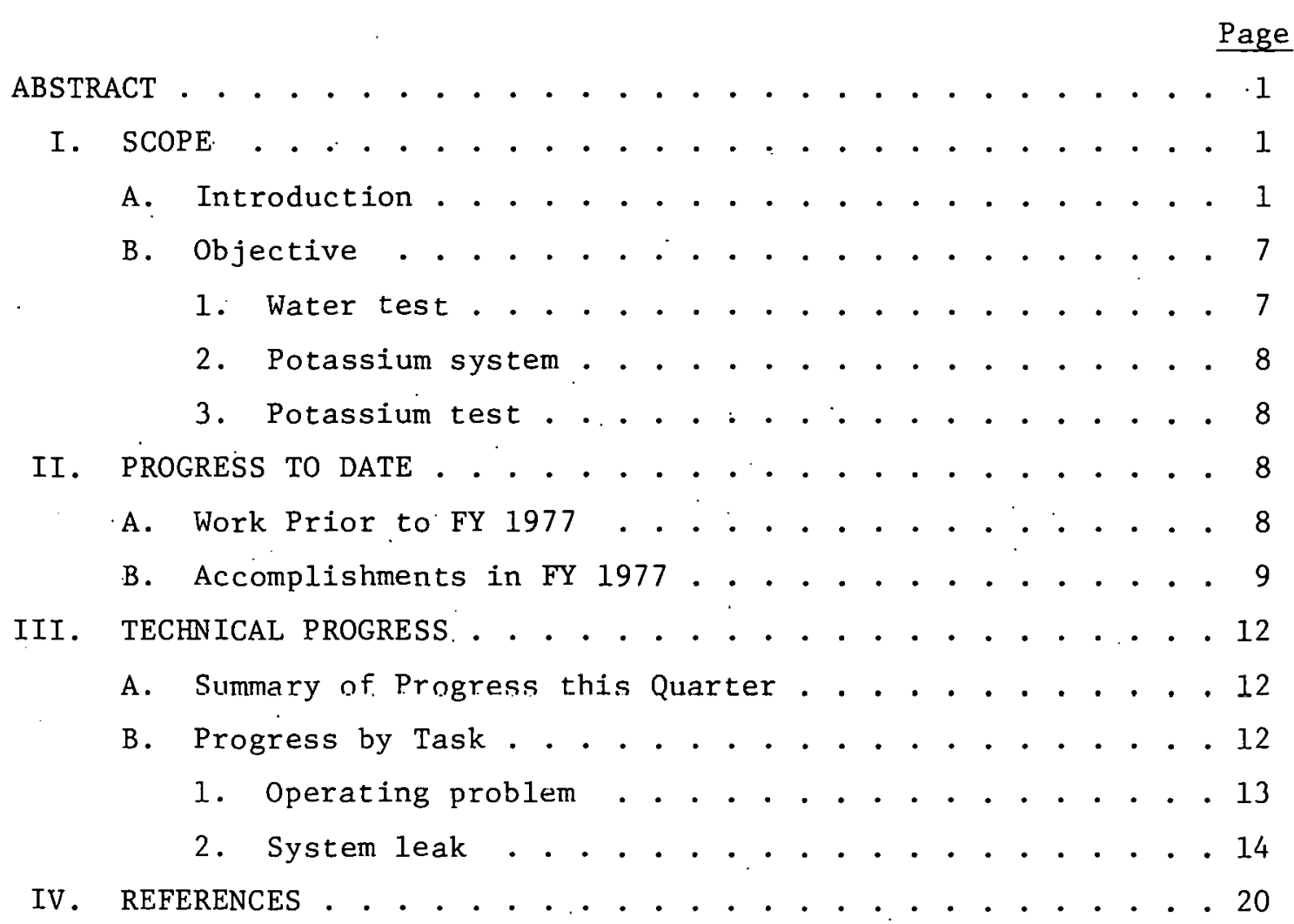




\author{
POTASSIUM VAPOR TOPPING CYCLE \\ TECHNICAL PROGRESS REPORT FOR PERIOD \\ OCTOBER 1, 1977 - DECEMBER 31, 1977 \\ Robert S. Holcomb
}

\begin{abstract}
The potassium vapor topping cycle is a concept for increasing the efficiency of the Rankine vapor cycle by raising the peak temperature by employing a potassium vapor cycle with a turbine inlet temperature of 1500 to $1600^{\circ} \mathrm{F}$ (815 to $870^{\circ} \mathrm{C}$ ) in which the waste heat rejected from the condensing potassium vapor is transferred to boiling water and steam in a conventional steam cycle. An efficiency of about $50 \%$ is calculated for this cycle with a natural circulation potassium boiler fired by gas or oil.

A DOE program is underway at ORNL to build a full-scale potassium boiler tube bundle and burner module and test it with water and then potassium. This is the fifth in a series of quarterly progress reports.

Operation of the boiler with potassium was initiated at the beginning of this quarter. Problems with plugging of the fill tank and condenser vent lines were encountered in the early runs. These problems were corrected and a boiling test run was made at a power level of about $1.9 \times 10^{6} \mathrm{Btu} / \mathrm{hr}$. A small potassium leak occurred in the liquid level indicator sheath, making it necessary to replace the level indicator with an alternate level indicator system that makes use of two argon bubbler tubes. The new level indicator was installed and the boiler was nearly ready for operation at the end of the quarter.
\end{abstract}

\title{
I. SCOPE
}

\section{A. Introduction}

An important step that can be taken to reduce our national fuel consumption is to increase the efficiency of our thermodynamic cycles. Few realize that a major factor in keeping our consumption from increasing more rapidly than it has during the pașt century has been an increase in the thermal efficiency of steam plants by about a factor of 8. Unfortunately, there has been no further increase since about 1950 
because at that time we reached the upper practicable temperature limit for the steam cycle; namely, about $1000^{\circ} \mathrm{F}\left(538^{\circ} \mathrm{C}\right)$. To reach higher thermal efficiencies it will be necessary to go to higher temperatures, and this in turn implies the use of other working fluids. A leading candidate for an advanced thermodynamic cycle is a potassium or cesium vapor cycle.

The approach proposed by ORNL entails raising the peak temperature of the thermodynamic cycle by employing a potassium vapor Rankine topping cycle that operates with a turbine inlet temperature of 1500 to $1600^{\circ} \mathrm{F}$ $\left(815\right.$ to $870^{\circ} \mathrm{C}$ ) and superimposed on a conventional steam cycle with a turbine inlet temperature of about $1000^{\circ} \mathrm{F}\left(538^{\circ} \mathrm{C}\right)$ by transferring the waste heat rejected from the condensing potassium vapor to the boiling water of the steam cycle. l Design studies have indicated that with a natural circulation boiler fired by gas or oil in a potassium topping cycle, a cycle efficiency of about $50 \%$ can be achieved. ${ }^{2}$

The basic layout of the power plant envisioned is shown in Fig. 1. Three basic systems are coupled to form the power plant, i.e., a gas turbine that supercharges the combustion chamber for the potassium boiler, the potassium vapor topping cycle, and an essentially standard steam cycle. The most important components involving new technology are the furnace-potassium boiler unit and the potassium condenser-slédill generator unit, both of which employ tube bundle modules as their basic unit of construction.

The ORNL gas- or oil-fired potasslum boiler concept employs a basic tube bundle module that consists of two annular rows of $1-1$. . (2.54 (ill) diameter stainléss steel cubes arranged alvund a $22-i n$. ( $56 \mathrm{~cm}$ ) diamctcr, long, vertical, cylindrical chamber. A full-scale test unit is shown in Fig. 2. The flame from the burner dirert.s hat gas upward through this combustion chamber. The tubes are bent at the top to provide flow passages between them so that the hot gas from the top of the combustion chamber can flow radially outward and then downward through an outer annulus over the outer row of tubes. To reduce the amount of heat transfer surface area required, the furnace and combustion chambers would be operated at a pressure of 6 to $10 \mathrm{~atm}$, i.e., substantially above the 


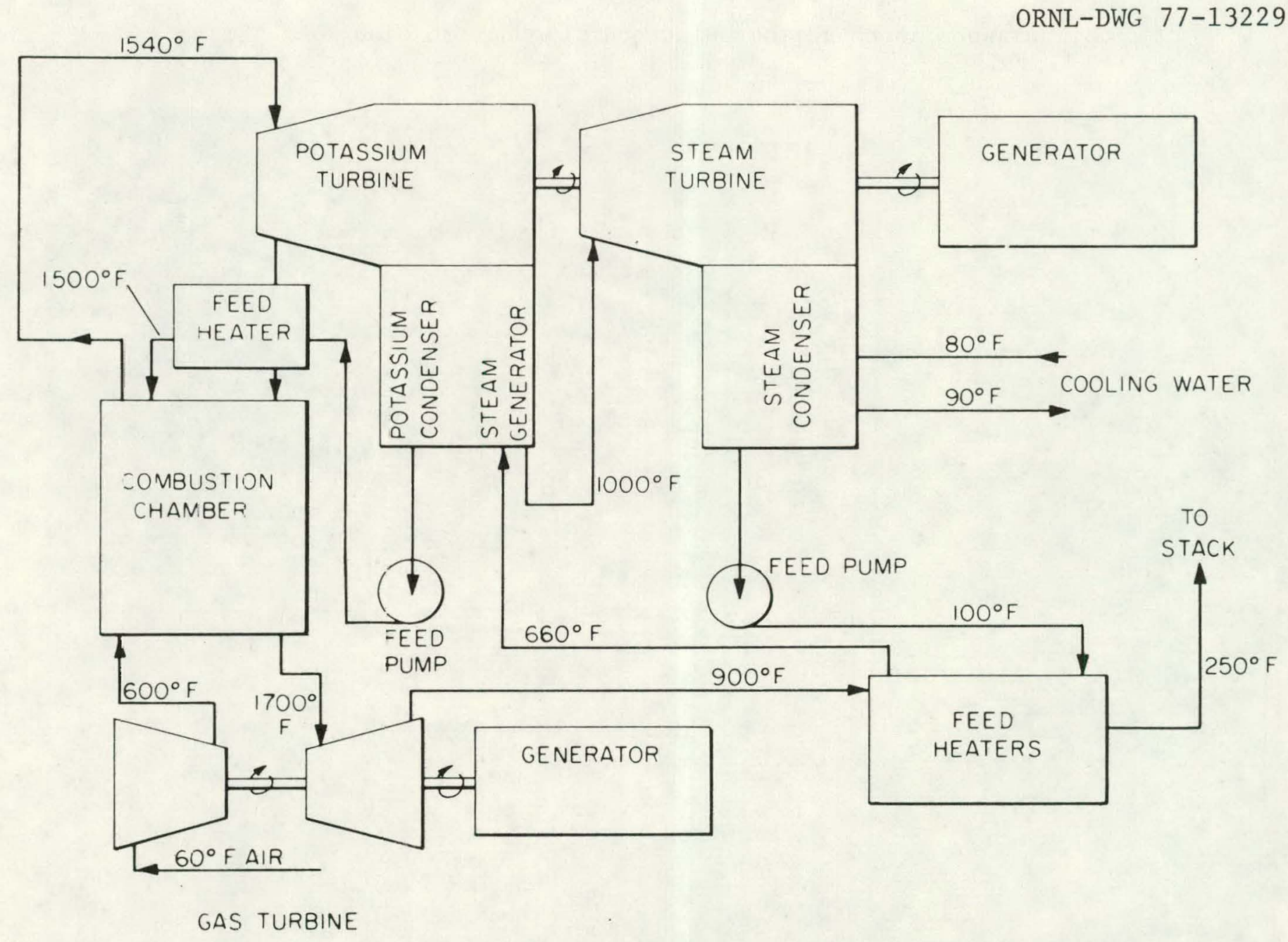

Fig. 1. Flowsheet for the proposed potassium vapor topping cycle system showing the relationships of the major components. 


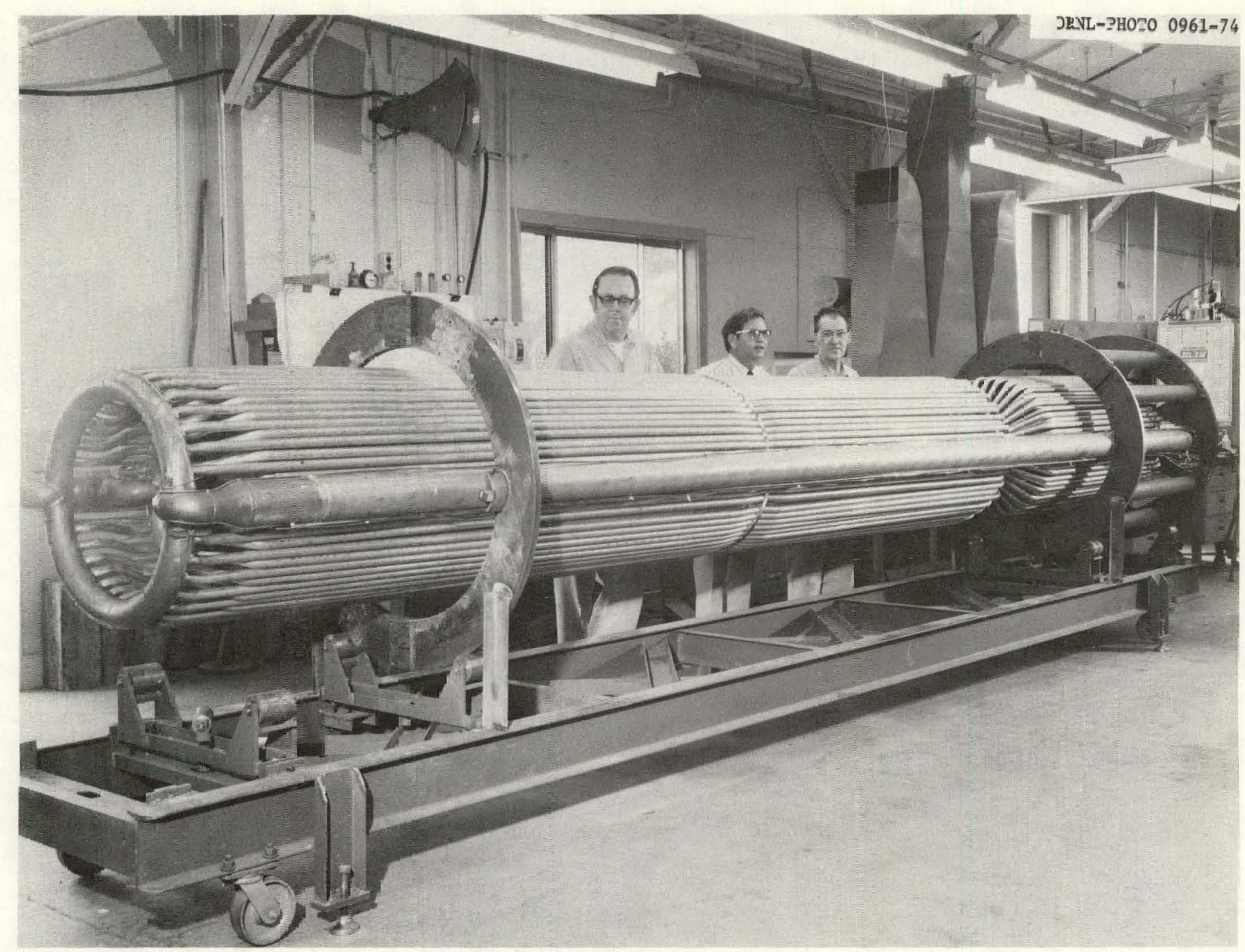

Fig. 2. Photc of the ORNL pctassium boiler under construction. 
2 atm which would be the design operating pressure of the potassium vapor system. Yotassium would circulate under natural thermal convection from a header tank at the top of the tube bundle through two downcomers, one on either side, to two ring-shaped manifolds at the bottom, and then vertically upward through the tubes back to a header drum and vapor separator at the top of the header tank.

Preliminary studies have also indicated that a particularly attractive system could be obtained by coupling a potassium or cesium vapor cycle to a fluidized bed coal combustion system. One very promising concept is a fluidized bed that would operate at a temperature of about $1700^{\circ} \mathrm{F}\left(927^{\circ} \mathrm{C}\right)$ and a pressure of about 5 atm. This pressure yields an acceptable pressure drop with a bed of sufficient depth to employ a vertical tube natural circulation boiler. To minimize the problems of turbine bucket erosion, corrosion, and deposits, the hot gases leaving the bed would be cooled to about $1000^{\circ} \mathrm{F}\left(538^{\circ} \mathrm{C}\right)$ before being admitted to a gas turbine to give a power output just sufficient to drive the compressor. The studies indicate that a cycle efficiency of about $48 \%$ can be achieved with this type of system.

The key factor in achieving the lower capital cost and higher thermal efficiency projected by the ORNL design lies in employing a vertical tube, natural circulation boiler rather than a horizontal tube, forced circulation boiler. Therefore, being a new design, it is very important that it be shown that the natural circulation boiler can be operated successfully. A program for testing a full-scale tube bundle and burner module first on water and then potassium was initiated to investigate the uncertainties that have become evident in the course of the design. These uncertainties fall into four major problem areas: burner performance; combustion gas heat transfer; flow distribution of the two-phase potassium liquid-vapor mixture and the tube bundle temperature distribution; and the vapor separator effectiveness. In many cases the cumulative uncertainties in the analysis are substantial and can be resolved only by obtaining test data. A section through the test module is shown in Fig. 3 . 
ORNL-DWG 77-13228

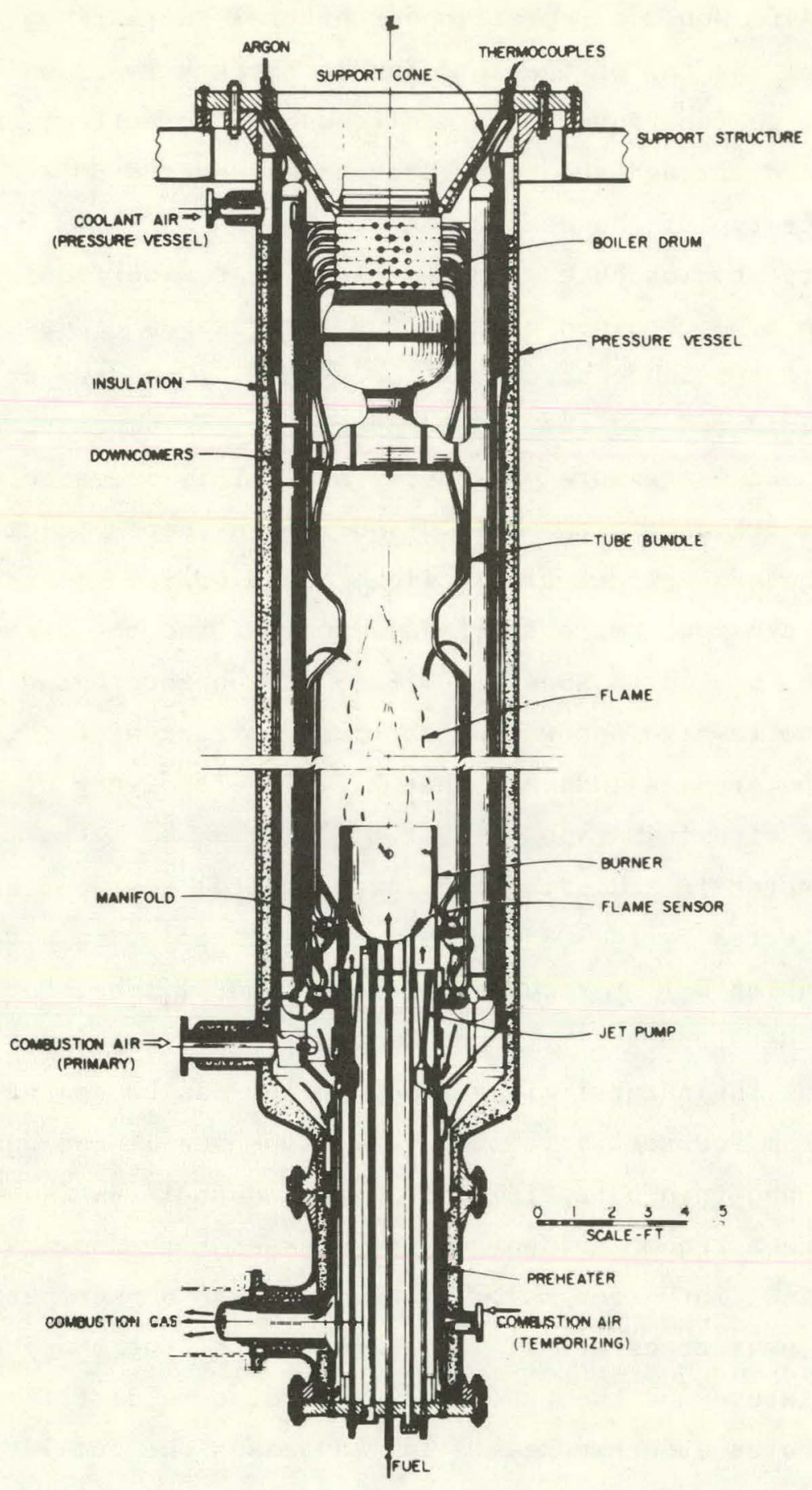

Fig. 3. Section through the gas-fired potassium boller tube bundle module, burner and furnace assembly. 
The water test was designed to get as detailed an insight into these problems as possible. The water tests were run with boiling at atmospheric pressure. In the first phase of the tests, the top of the boiler drum was open so that visual observation of the flow from the boiler tubes was possible. The boiler drum being open also made it much easier to install instrumentation to obtain a more detailed picture of the flow distribution than will be the case in the tests with potassium.

The potassium test will provide a test of the boiler bundle and furnace at the design conditions of full pressure and temperature for potassium operation. While visual observation and measurement of flows from each boiler tube cannot be done while operating with potassium, the tube bundle temperature distribution will provide an indication of the potassium two-phase flow distribution.

The results obtained from the test program will provide boiler design data that will be beneficial to both gas-fired and fluidized bed coal-fired systems.

\section{B. Objective}

The overall objectives of the program are to complete the water test; design, fabricate and install the potassium system; and run the potassium test.

\section{Water test}

a. Check out the boiler and furnace.

b. Check out combustion air seals.

c. Measure tube bundle and flue gas temperature distribution.

d. Observe argon distribution.

e. Operate at a power level of $2 \times 10^{6} \mathrm{Btu} / \mathrm{hr}$.

f. Observe boiling stability.

g. Establish minimum power level for stable boiling in outer tube bank.

h. Measure heat load on individual boiler tubes.

i. Observe vapor separator performance. 
2. Potassium system
a. Complete the design of components and modifications for the potassium system.
b. Perform system modifications and fabrication of components, including tower extension, condenser, drain tank, piping, sample box, electrical system, instruments and controls.
c. Install the potassium system components.

3. Potassium test
a. Check out system.
b. Medsule tubc bundle and flup gas temperature dislitibution.
c. Monitor boiling nucleation problem.
d. Operate at power levels up to $4 \times 10^{6} \mathrm{Rt} 11 / \mathrm{hr}$.
e. Observe 1iquid level control.
f. Observe vapor separator performance.
g. Run $2000 \mathrm{hr}$ endurance test.
h. Determine minimum argon flow required for nucleation.

\section{IT. PROGRESS TO DATE}

\section{A. Work Prior to FY 1977}

Work on alkali metal vapor cycles at ORNL began with snme design studies under the Aircraft Nuclear Propulsion program in 1954 and was resumed in 1958 with studies of nuclear electric space power plants. This led to an extensive series of component and system tests in the course of which 4200,000 hr of boillng pulassium systcm operation were obtained in the early and midule 1960's. When the pressing need for reductions in both fuel consumption and heat rejection to the environ menl became evident in 1970, a design study of a potassium vapor cycle plant was carried out under NSF sponsorship. ${ }^{1-3}$ This plant was designed to operate on clean gaseous fuel derived from coal, the preferred fue1of-the-future for central stations at that time. The study showed that the greatest uncertainties from both the design and cost standpoints lay in the potassium boiler, and that these could be resolved best by designing, building, and testing a full-scale tube bundle and burner 
module first with water and then potassium. Funds to begin this work were made available by NSF in July, 1972, and NSF funding was continued in 1973. When ERDA was proposed in June, 1973, the responsibility for the potassium vapor cycle work became uncertain, with NSF, the AEC, OCR, and NASA all having claims in this area. As a consequence of these uncertainties, the program remained unfunded through 1974 until ERDA was formed at which time some interim funds were made available from NSF, and funds from ERDA-FE finally became available at ORNL for the program in December, 1975.

The shakedown and performance tests of the burner operating outside the boiler in the open air were completed in May, 1976. The water system installation was completed and the water test was begun in July 1976. Detailed design of the potassium system was resumed in April, 1976, and much of the work was completed by the end of September. Fabrication of components for the potassium system such as the condenser and drain tank was initiated in August.

\section{B. Accomplishments in FY 1977}

The water test program was completed in March. ${ }^{4}, 5$ The tests included measurement of the argon distribution, heat load of individual boiler tubes, boiler temperature distribution, combustion gas temperature distribution, combustion air pressure drop and vapor separator performance. Boiler preheating tests were run, and it was concluded that an external air preheater was needed for preheating the boiler before filling with potassium.

The design of the potassium test system was completed in June. ${ }^{6}$ An elevation drawing of the system is shown in Fig. 4. Installation of the major components for the potassium system and construction work on the equipment tower was completed in June. A photograph of the equipment tower after completion of construction is shown in Fig. 5. The piping and electrical wiring was installed during the last quarter of FY 1977, and the potassium system installation was completed in September. ${ }^{7}$ The checkout of the instruments and controls was nearly completed. The fill 


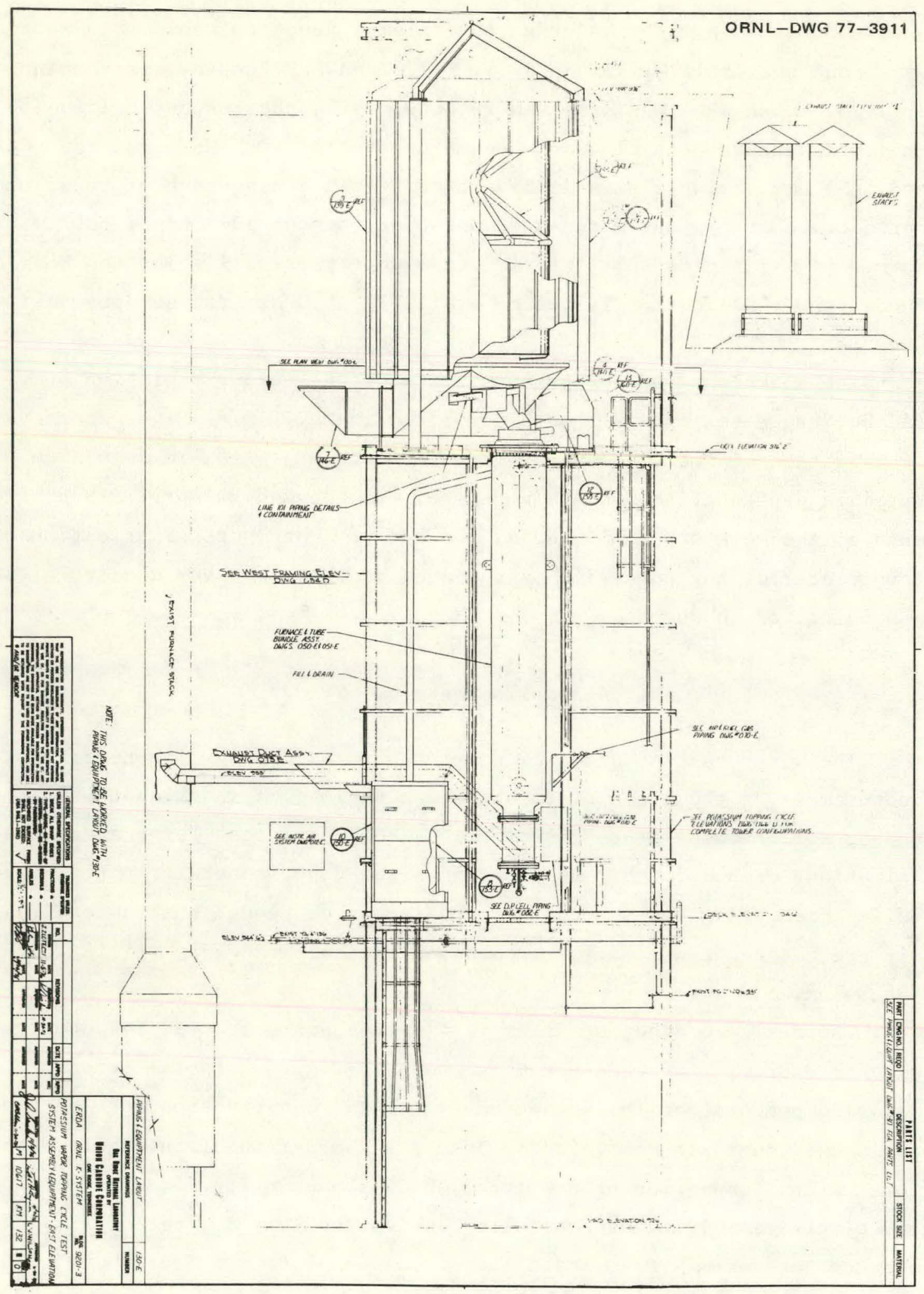

Fig. 4. Elevation drawing of the potassium test system. 


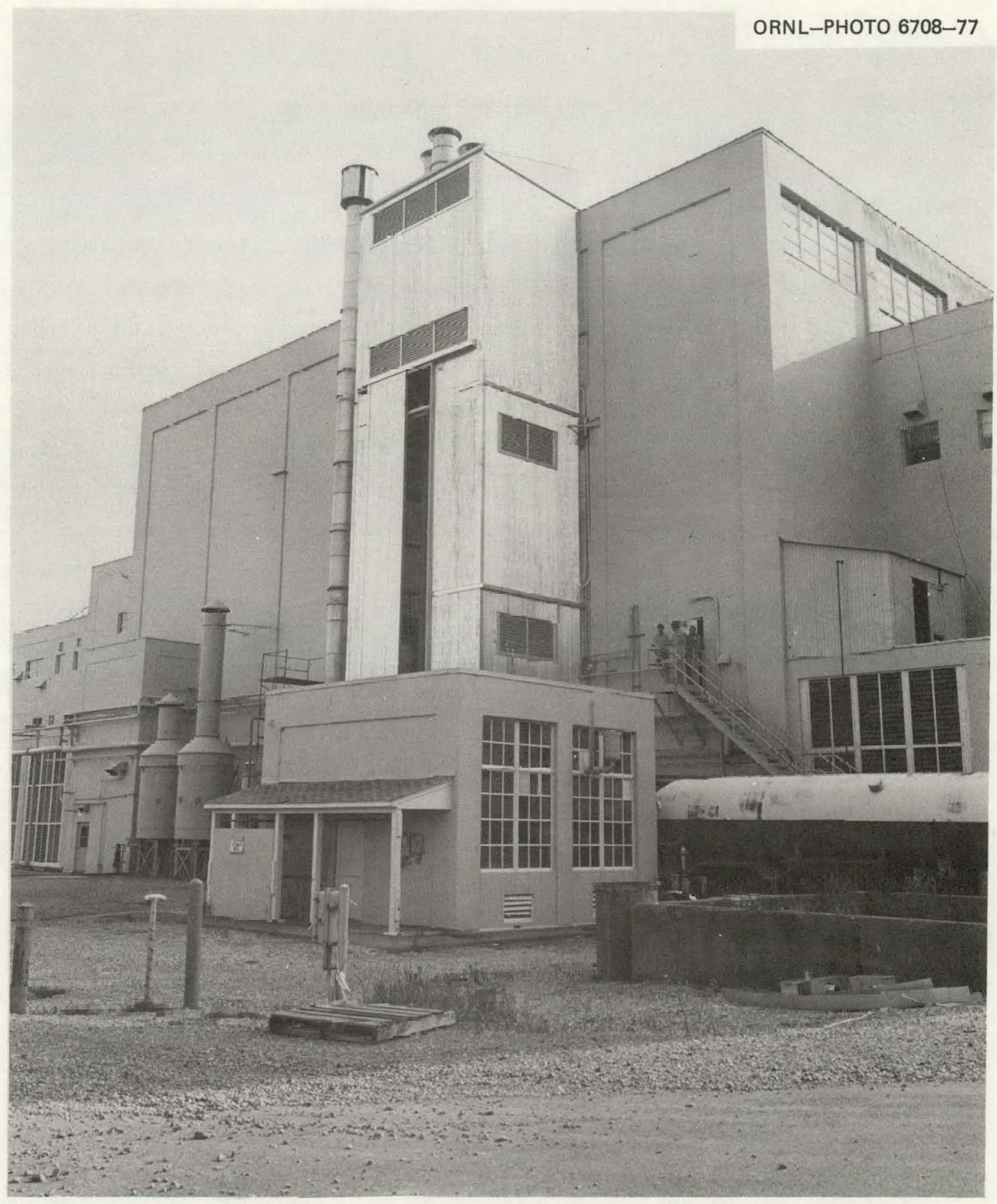

Fig. 5. Equipment tower after completion of construction. 
and drain tank was filled with potassium in preparation for initial filling of the boiler.

\section{TECHNICAL PROGRESS}

\section{A. Summary of Progress this Quarter}

Operation of the boiler with potassium was initiated in October. The first three runs were for short periods without sustained boiling. Two operating problems were encountered in these runs: pligging of the argon nucleators after the boiler was drained and refilled, and plugging of small valves in the vent lines from the fill tank and from the condenser.

It was found that the argon flow could be reestablished by raising the system temperature and applying momentary high pressure to the nucleator line. The cooling of the vapor trap in the fill tank vent line was increased to prevent plugging in that line. A vapor trap employing a column of low temperature liquid potassium was installed in the condenser vent line to prevent plugging there.

A boiling run of about 50 min duration was then made with a burner power level of about $1.9 \times 10^{6} \mathrm{Btu} / \mathrm{hl}$. During this run a small potassium leak occurred in the welding nozzle connecting the boiler liquid level indicator lead sheath to the potassium liquid return line. Attempts to repair the level indicator leads were unsuccessful, and it became necessary to install an alternate liquid level indicator. A level indicator which makes use of two argon bubbler tubes was chosen and has been installed. It is expected that the secondary containment will be reinstalled and the system will be ready for operation by mid-January.

\section{B. Progress by Task}

The checkout of the instrument and control system was completed in early October, and the potassium system was made ready for initial operation.

The potassium in the fill and drain tank was heated to $1200^{\circ} \mathrm{F}$ to allow the zirconium foil in the tank to remove oxygen from the potassium. 
The potassium boiler, condenser and piping were evacuated and back filled with argon several times to remove oxygen and water vapor from the system. The system was heated with the electrical line heaters and the furnace preheater.

The boiler was filled with potassium and heated with the main burner on three separate occasions; each time the potassium was returned to the drain tank. Each of these runs was short term, and at no time was there any indication that full-fledged boiling had begun. Samples of the potassium were taken during the first fill and again during the first drain. Analyses of these samples indicated that the oxygen content in the potassium was between 7 and $12 \mathrm{ppm}$.

\section{Operating problems}

Two operating problems were encountered in the initial runs on the boiler. One problem observed was the plugging of the argon nucleators after the boiler was drained and refilled. The second problem was plugging of small valves in the vent lines from the fill tank and from the condenser.

Plugging of the argon nucleators was observed after the boiler was drained and refilled. It was found that the argon flow could be reestablished by raising the system temperature and applying momentary high pressure to the nucleator line.

When the drain tank was heated to purify the potassium, it was not possible to adequately cool the vapor trap, and it became hotter than it should for proper operation. As a result, a small amount of potassium migrated into the vent line and partially plugged the vent valve. The vent line and valve were removed, cleaned and reinstalled. The insulation on the vapor trap was reworked, and provision was made to supply forced air cooling of the trap during subsequent operation when the temperature of the trap might tend to rise too high.

Potassium also collected in the check valve in the condenser vent line after the third period of short term operation.

A low temperature $\left(200^{\circ} \mathrm{F}\right)$ potassium bubbler trap was fabricated and installed in the vent line. Such traps have proven effective in similar applications. 
An analysis was made on the argon gas being used for nucleation and general cover gas purposes. The results of the analysis indicated; nitrogen - $10 \mathrm{ppm}$, hydrogen - $5 \mathrm{ppm}$, oxygen - less than $5 \mathrm{ppm}$.

After the modifications to the drain tank and condenser vent lines to prevent plugging were completed, the system was heated, purged and refilled with potassium, and operation was resumed on November 7 .

The system was heated up slowly to avoid thermal stresses, and the burner was stopped periodically to observe and evaluate temperatures of the hniler tubes and the condenser. The butues power lovol was gradually increased to $1.9 \times 10^{6} \mathrm{Btu} / \mathrm{hr}$. At Lhis puwir level the indicated potassium temperature in the boiler drum was about $1560^{\circ} \mathrm{F}\left(849^{\circ} \mathrm{C}\right)$, which is in good agreement with the saturation temperatuse at the boiler drum pressure, thus indicating that boiling was occurring in the tubes. The pressure drop reading in the downcomers indicated good flow in the downcomers during boiling. A run of about 50 min was made at this power level, and the system was shut down for the day.

\section{System leak}

During the run on the afternoon of November 7 , the upper liquid level indicator in the boiler drum began malfunctioning. The following day during preparation for anuther run, some potassium was found where the boiler liquid level indicator leads exit from the secondary containment of the potassium liquid return line. The system was shut down, and the sernndary containment was removed from the 1 iquid return line. A potassium leak was tound to have occurred through a very small area of porosity through Llie wclding nozzle for the upper liquid level indicator sheath. Further examination revealed that there were cracks in the 1iquid 1evel indicator sheath tubes that apparently had been caused by the tube having been inadvertently bent severely during the condenser installation and then straightened back to the proper location. The potassium that had leaked through the porosity in the metal had then entered the liquid level indicator sheath tubes through the cracks. Potassium liquid and vapor had reacted with the air, the liquid level indicator lead wires and the magnesium oxide powder insulation around the lead wires. 
The sheath tubes were cut off, and the hard reaction products were removed from around the sheath wires to a depth of several inches below where the potassium had entered the cracks in the sheaths. An attempt was made to make electrical resistance measurements on the indicator leads, but as this was being done, the weakened lead wires broke at a point inside the sheath tube below the level where it penetrates the liquid return line sealing cap. This made it impractical to repair the liquid level indicator leads and made it necessary to abandon the use of the liquid level indicator and choose another method for measuring the boiler drum liquid level that could be installed within a reasonable length of time.

It was decided to make use of argon bubbler tubes to measure the liquid level by a differential pressure reading as had been done in the boiler liquid downcomers. This required that one argon tube be installed through the liquid return line and inserted down to the bottom of the boiler drum, and a second argon tube be installed through a hole drilled through the top cap of the boiler drum and inserted into the vapor space in the vapor separator.

The level element sheaths and the thermowell were flushed with a $10 \%$ solution of nitric acid and flushed with distilled water and then alcohol in an effort to remove any remaining potassium oxide or potassium hydroxide from the system. These were then dried out by evacuating them for several days. When the pressure reached 15 torr, the furnace preheater was set at $400^{\circ} \mathrm{F}\left(204^{\circ} \mathrm{C}\right)$, and evacuation continued for another 24 hr.

A cap was welded over the cutoff indicator sheaths to seal the area where the leak occurred, and the argon bubbler tube was inserted along with a thermowell into the bottom of the boiler drum and welded in place. A hole was drilled through the top cap of the boiler drum with internal argon pressure on the boiler to prevent air leakage. A small cap was welded over the hole, and the argon bubbler tube was inserted through a hole in the cap, and the tube was welded to the cap. The vapor separator space was $x$-rayed before and after the tube was installed to insure that it was placed at the proper location. Figure 6 shows the 


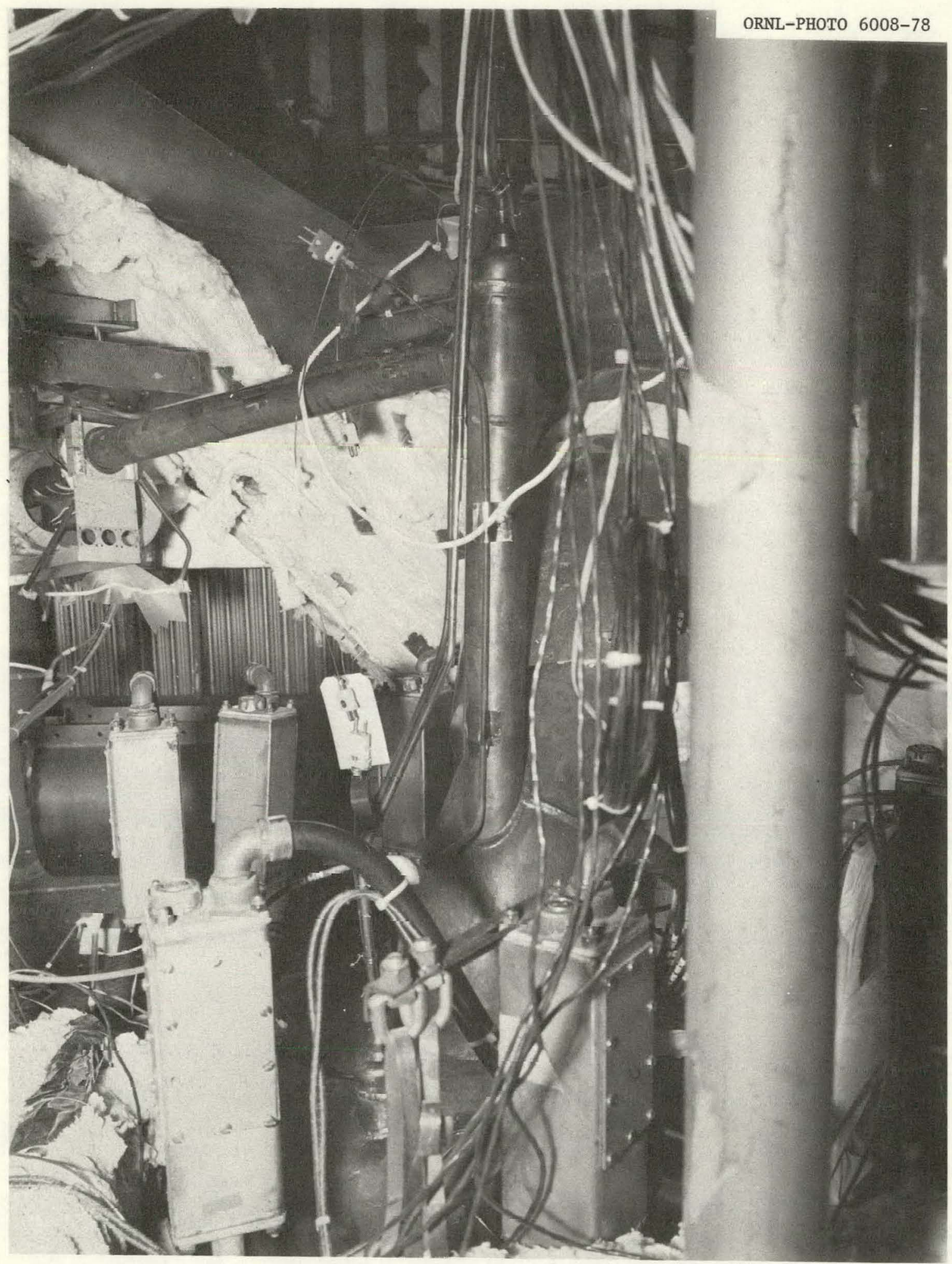

Fig. 6. View of the top of the boiler drum with the argon bubbler level indicator system installed. 
top of the boiler drum and the potassium return line with the argon bubbler liquid level indicator system installed. Argon lines were run from the control room and connected to the bubbler tubes. A differential pressure transmitter was calibrated and connected across the argon bubbler lines with potassium vapor traps installed in the argon lines. Figure 7 shows the penetration of the vapor traps through the condenser enclosure, and Fig. 8 shows the differential pressure cell mounted on the outside of the condenser enclosure.

Several new heaters and thermocouples have been installed on the new piping and connected in the control room. The thermal insulation has been replaced, and modification and reinstallation of the secondary containment are presently underway. It is expected that the system will be ready for operation by mid-January. 




Fig. 7. Potassium vapor traps for argon bubbler tubes. 


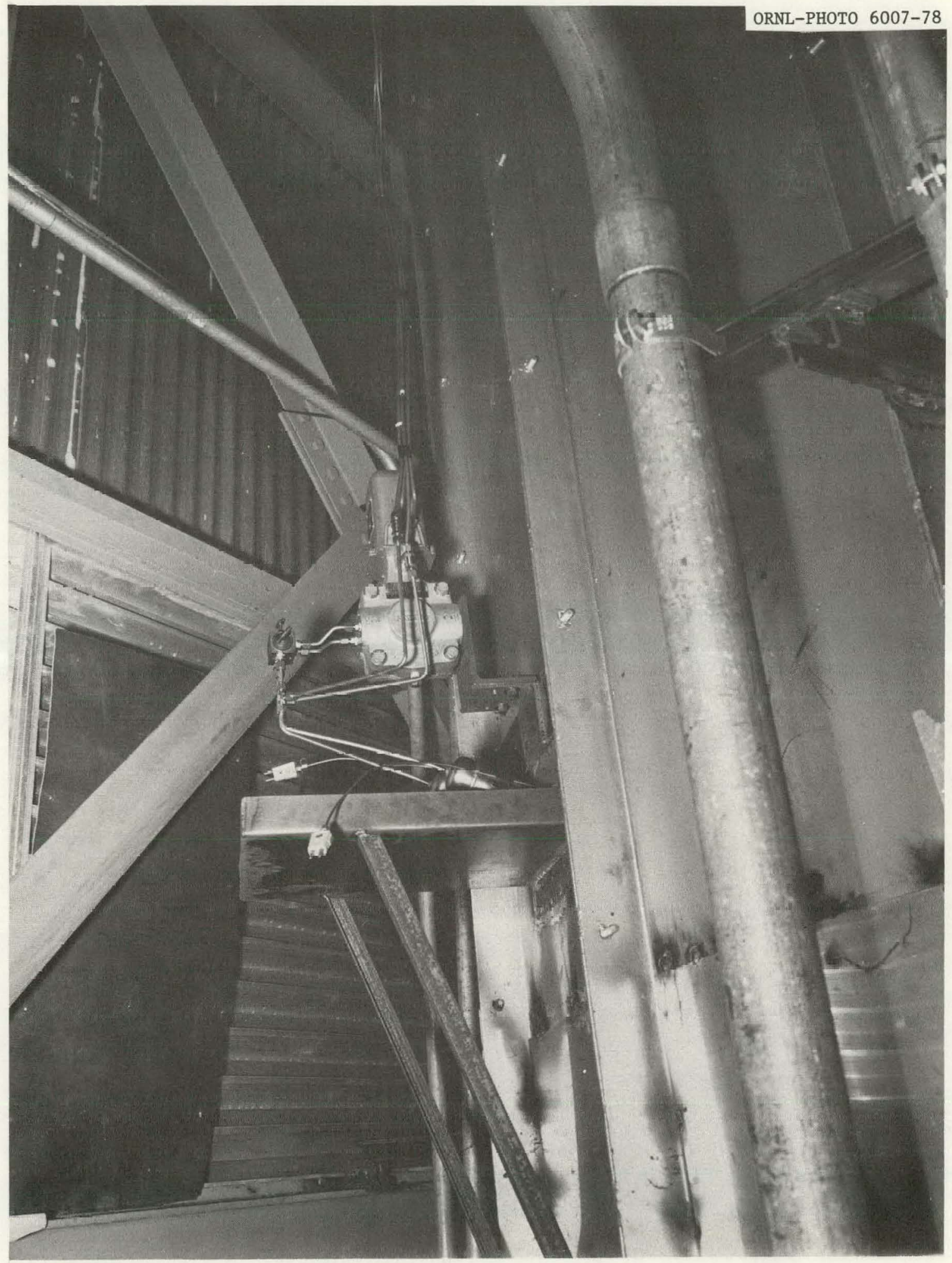

Fig. 8. Differential pressure transmitter for argon bubbler level indicator system. 


\section{REFERENCES}

1. A. P. Fraas, Preliminary Assessment of a Potassium-Steam-Gas Vapor Cycle for a Better Fuel Economy and Reduced Thermal Pollution, ORNLNSF-EP-6, Oak Ridge National Laboratory, (August 1971).

2. M. E. Lackey, Second Iteration Analysis of a Fossil Fuel-Fired Gas Turbine-Potassium-Steam Combined Cycle, ORNL-NSF-EP-39, Oak Ridge National Laboratory, (July 1973).

3. A. P. Fraas, Operational, Maintenance and Environmental Problems Associated with a Fossil-Fuel-Fired Potassium-Steam Binary Vapor Cycle, ORNL-NSF-EP-30, Oak Ridge National Laboratory (August 1974).

4. R. S. Holcomb, Potassium Vapor Topping Cycle, First Quarterly Technical Progress Report, for Period October I to December 31, 1976, ORNL/TM5954, Oak Ridge National Laboratory, (August 1977).

5. R. S. Holcomb, Potassium Vapor Topping Cycle, Second Quarterly Technical Progress Report, for Period January I to March 31, 1977, Oak Ridge National Laboratory, (to be published).

6. R. S. Holcomb, Potassium Vapor Topping Cycle, Third Quarterly Technical Progress Report, for Period April 1, 1977 to June 30, 1977, Oak Ridge National Laboratory, (to be published).

7. R. S. Holcomb, Potassium Vapor Topping Cycle Technical Progress Report for Period July 1, 1977 to September 30, 1977, ORNL/TM-6153, Oak Ridge National Laboratory, (February 1978). 
ORNL/ TM-6314

Dist. Category UC-90f

INTERNAL DISTRIBUTION

1. S. I. Auerbach

2. Seymour Baron

3. M. Bender

4. R. E. Brooksbank

5. D. A. Canonico

6. W. E. Cooper

7. J. H. DeVan

8. D. E. Ferguson

9. L. M. Ferris

10. A. P. Fraas (Consultant)

11. W. Fulkerson

12. R. L. Graves

13. W. L. Greenstreet

14. R. H. Guymon

15. J. F. Harvey

16-25. R. S. Holcomb

26. G. R. Jasny, $Y-12$

27. J. E. Jones

28. M. A. Karnitz

29. M. E. Lackey

30. Milton Levenson

31. D. B. Lloyd

32. R. E. MacPherson

33. A. P. Malinauskas
34-38. L. E. McNeese

39. J. R. McWherter

40-42. W. R. Mixon

43. L. C. Oakes

44-45. T. W. Pickel

46. H. Postma

47. M. W. Rosenthal

48. T. H. Row

49. Royes Salmon

50. G. Samuels

51. C. D. Scott

52. I. Spiewak

53. H. E. Trammell

54. D. B. Trauger

55. G. D. Whitman

56. M. K. Wilkinson

57. L. V. Wilson

58. R. G. Wymer

59. G. P. Zimmerman

60. Lab Records - RC

61-62. Lab Records

63-64. Central Research Library

65. Document Reference Section

66. ORNL Patent Office

\section{EXTERNAL DIŚTRIBUTION}

67. E. K. Bastress, Advanced Power Systems, Fossil Energy Program, DOE, Washington; D. C. 20545

68. R. G. Chenoweth, Jr., Union Carbide Corporation, Chemicals and Plastics Division, South Charleston, West Virginia 25303

69. W. M. Crim, Advanced Power Systems, Fossil Energy Program, DOE, Washington, D. C. 20545

70. H. Falkenberry, Tennessee Valley Authorty, Chattanooga, Tennessee 37401

71-72. Steven Freedman, Advanced Power Systems, Fossil Energy Program, DOE, Washington, D. C. 20545

73-82. Carey Kinney, Advanced Power Systems, Fossil Energy Program, DOE, Washington, D. C. 20545

83. John A. Belding, Advanced Power Systems, Fossil Energy Program, DOE, Washington, D. C. 20545

84. Director, Research and Technical Support Division, DOE-ORO

85-324. P. O. Box 62, Oak Ridge, TN 37830 (for distribution as shown in TID-4500 Distribution Category UC-90f) 